\title{
Industry 4.0 and some social consequences: Impact assessment by microsimulation for Hungary
}

\author{
ILONA CSERHÁTI ${ }^{1 *}$ and KÁROLY PIRISI ${ }^{2}$
}

${ }^{1}$ Department of Statistics, Corvinus University of Budapest, Hungary

${ }^{2}$ Department of International Trade and Logistics, Budapest Business School, Hungary

Received: 26 August 2019 • Revised manuscript received: 15 April 2020 • Accepted: 19 April $2020 \bullet$

Published online: 23 June 2020

(c) 2020 The Author(s)

\begin{abstract}
The expected future impact of the fourth industrial revolution is a hotly debated issue in the literature. The majority of papers focus on quantifying the expected impacts on labour demand, or on a specific country, or on huge macro-regions - and the estimates differ widely. Our paper focuses on the impact assessment of Industry 4.0 on the expected structure of employment, wages and inequalities in Hungary. We built a static microsimulation model for our analysis, where the "EU Survey of Income and Living Conditions Hungary 2017" dataset was used as a starting point. Projections by the European Centre for the Development of Vocational Training (CEDEFOP) were used for policy simulations on future employment by sector and by occupational group for each European Union (EU) member state. The analysis also elaborates our own augmented vision about the expected labour demand changes and expected wage trends. Based on this information, the spill-over effects were calculated regarding wage structure and inequalities by sector, region and the highest educational attainment.
\end{abstract}

\section{KEYWORDS}

employment, labour demand, wage structure, skills, microsimulation

\section{JEL CODES}

$\mathrm{J} 21, \mathrm{~J} 31, \mathrm{~J} 23, \mathrm{~J} 24, \mathrm{C} 81$

\footnotetext{
*Corresponding author. E-mail: ilona.cserhati@uni-corvinus.hu
} 


\section{INTRODUCTION}

Industrial revolutions usually lead to a huge polarisation of wealth and power, followed by several measures, including taxation, development of social safety nets and actions by trade unions, to offset the harmful consequences (WEF 2016). Regarding the fourth industrial revolution, the expected changes and challenges are so profound that it is crucial to prepare both economic policy decision-makers and employers for absorbing the new ways of thinking and the new speed of innovation changes (Landmann - Heumann 2016; Verhofstadt 2017). The future is happening right now (Wike - Stokes 2018), and we have to cope with new types of challenges and be prepared for them. But, for that, a lot of information is needed (Deloitte 2019; SZTAKI 2018).

Therefore, it is essential to elaborate models for policy analysis to produce credible evidence to answer questions that policy makers care about: What could the future of work and labour market look like?; How can the distributional effects be quantified; and What will be the most important implications of the development process as a whole?

In order to support this, the paper provides estimates on the expected labour market impacts and the distributional effects of automation for Hungary until the year 2030. We have built a microsimulation model where we took into consideration both the population projections from both the European Centre for the Development of Vocational Training (CEDEFOP) and the Hungarian Central Statistical Office (HCSO), which differ quite sharply in terms of assumptions on net migration to Hungary. Regarding labour supply, we used the assumption that size and structure of the labour supply would be unchanged or it could even deteriorate due to the rigidness in the education system and also due to the fact that the different structures of migration inflows and outflows in terms of educational levels are not favourable for Hungary. It can be also argued that the relationship between the education system and labour supply structure is vague and can only be transformed on the longer run. Regarding future demand for labour by sector and occupation, we used the CEDEFOP (CEDEFOP 2018) forecasts for 2030.

The outline of the paper is as follows. Section 2 gives a brief overview of the current literature, taking into consideration the unavoidable megatrends as well as the country-specific aspects. Section 3 describes the main characteristics of the microsimulation dataset and also gives a brief overview of the demographic trends and the different demographic scenarios used in the analysis, as well as their consequences for the size and structure of Hungarian labour demand and supply. In Section 4, the main assumptions for the labour demand and real wages are presented at sectoral level, and the main results of the different scenarios are shown, followed by concluding remarks.

\section{LITERATURE REVIEW AND SOME SPECIFIC ISSUES OF THE HUNGARIAN CASE}

Microsimulation modelling is a micro-based methodology that can be used for the analysis of micro-units such as individuals, households or corporations. This micro-based simulation modelling technique originated from Orcutt (1960), but the spread of microsimulation methodology was quite limited until the early 1990s due to lack of computer capacities and insufficient accessibility of micro-data. Economic microsimulation models can be categorized as static 
or dynamic. Static models take the characteristics of individuals (gender, age, family type, employment status, etc.) as exogenous, while dynamic models try to follow the evolution of these characteristics one-by-one either through behavioural responses or pre-determined rules.

Static microsimulation models, where the temporal dimension and behavioural response elements are excluded, are more widely used in social sciences. These models focus on the dayafter impacts and concentrate mainly on distributional effects of possible (mainly fiscal) policy changes (Sutherland 1995). It can be an important question for economic policy decision makers on how incomes or living conditions of certain social groups change in response to certain government measures. At first, some national static tax-benefit models were elaborated (Bitler et al. 2006; Wagenhals 2004) and the relevant microsimulation techniques were discussed for impact assessment of fiscal policies (Bitler et al. 2006; Bourguignon - Spadaro 2006). For the specific case of Hungary, Szívós et al. (1998) applied a static microsimulation model (TÁRSZIM) for the analysis of taxes and benefits. After the EU enlargement in 2004, microsimulation tools were increasingly applied in Central and Eastern Europe for analysing the effectiveness of planned or already implemented economic policy measures (Benedek - Kiss 2011; Benedek Lelkes 2006; Cserháti et al. 2007; Gupta - Kapur 2000). EUROMOD, the official tax-benefit microsimulation model of the EU, went one step further, allowing some international comparisons across different EU countries regarding the impacts of taxes and benefits on the distribution and composition of incomes (Atkinson 2009; Paulus et al. 2009; Sutherland - Figari 2013).

The analysis of income inequalities in Hungary by microsimulation techniques has become widespread during and after the great recession (Cserháti et al. 2012; Cserháti - Takács 2010), and the possible distributional impacts of a flat-rate income tax system were also analysed by Benedek and Kiss (2011).

Data reliability is of crucial importance for a microsimulation model for policymaking. Generally, microsimulation models use micro-level surveys (household budget or income surveys, etc.) as primary sources. However, consistency had to be created among micro-data collected from the survey and macro-data taken from other sources if one aims to use the model results for actual decision making. Data issues and the methodology of solving these issues were overviewed in some papers (Bargain -Callan 2010; Cserháti - Keresztély 2012), and Bourguignon et al. (2008) presented a comprehensive array of macro-micro modelling frameworks, which combine macro-models with microsimulation models. Colombo (2010) also showed an overview of different linking approaches focussing on connecting Computable General Equilibrium (CGE) and microsimulation models, allowing to take into consideration the general equilibrium effects of a proposed fiscal policy change. Peichl (2009) also analysed the benefits and problems of linking micro- and macro-models. Based on these methodological developments, impact assessments of longer term development or structural reforms on the labour market have become possible. Norton (2017) explored the ways in which the fourth industrial revolution can affect developing countries and their income distribution. Cserháti and Takács (2018) analysed the expected labour market impacts of automation and its impact on the poverty gap. It was concluded that technological development without targeted policy measures can increase both inequality and poverty, quite significantly.

This paper focuses on the impacts of automation on the labour market and on the possible spillover effects regarding income distribution and expected inequality trends. We use the static microsimulation modelling approach, simulating the expected labour market movements by 
reweighting the micro-dataset. Based on the assumptions on demographic movements and sector-level labour demand and supply discrepancies, several income and income inequality measures can be calculated (by region, the highest educational attainment, sector, etc.). By applying this method, a static microsimulation model can be a useful tool for analysing longterm inequality impacts of different macroeconomic scenarios regarding technological development and the expected changes in forms and structure of employment, i.e. the future of work.

The three industrial revolutions recorded in history so far exerted a direct and immediate effect, typically within the industry. However, changes experienced today in the industrial field have presumably been driven by partly independent, self-learning technology with memory, inspired by the fast development of digital technology. To adapt to this development, an increasingly open and flexible institutional system is necessary that has an effect on many fields, even beyond industry, in areas like social and economic cooperation.

One of these social institutions is the labour market, where there is a consensus that a wellfunctioning labour market promotes innovation. Companies aiming at innovation can grasp the opportunities of training adjusted to the needs of simplified labour hiring and dismissal offered by the labour market. Selection of appropriate labour is facilitated by applying big data procedures (Isson - Harriott 2016).

Two key factors should be highlighted in the context of implementing an efficient employment policy. First, essential condition in the deliberate influencing of labour market processes is transparency, i.e. to have adequate short-, medium- and long-term labour market forecasts on the supply and demand side alike. The second condition is the establishment and efficient operation of an institutional system designed for the treatment of unemployment (Pirisi 2017).

For the sake of drawing up the most accurate labour market prognoses possible, the literature has paid special attention to the topic of Industry 4.0, commensurate with its weight (Fülöp 2018). Part of the technical literature draws attention to the structural changes of labour demand due to the expected technological development in a given country, considering its demographic situation, economic structure and role in the international division of labour or in a broader outlook (Acemoglu - Restrepo 2019). Another part of literature tries to foresee more specific labour market effects. Some of these contributions are pessimistic concerning the expected labour demand. For example, a paper in this category applies estimation and statistical modelling to come to the conclusion that $47 \%$ of today's jobs would be lost with a probability higher than $70 \%$ in the USA (Frey - Osborn 2013). Another paper investigating the economic role of industry in Europe found that employees with low qualifications would be the most affected by the disappearance of industrial jobs. The number of employees with higher qualifications show an increasing tendency (Rodrik 2016). An analysis examining the OECD countries using secondary data analysis found that an average $9 \%$ of jobs could be automated in these countries (Arntz et al. 2016). A research group commissioned by the World Bank performing corporate data analysis found (based on production and import data from the US, China and Mexico) that the use of a new robot reduces the population-proportional employment by $0.18-0.34 \%$ and average wages by $0.25-0.5 \%$.

At the same time, according to a macro-simulation study (Cette et al. 2016), if less strict labour regulations were introduced in the EU, the share of employees with higher qualification would decrease within the total headcount of those in employment faster than the rate of increase of those with low schooling. The first would decrease by around 13\% in Germany and 
Austria and by $23 \%$ in France. The driver of this development is the appearance of the relatively higher cost-savings generated by the dismissal of those with higher schooling, as extra investment funds providing an opportunity for the replacement of a higher proportion of those with higher qualification.

As for Hungary, according to analysis based on corporate surveys and focussing on jobs replaceable by automation, about 500 thousand jobs are estimated to be lost (Nábelek et al. 2016). There are several other rather pessimistic views in the literature regarding the Hungarian case such as Fine et al. (2018), who firmly argued that half of the working hours in Hungary would be done by robots.

A paper presenting more optimistic findings examined 46 countries of different development levels and came to the conclusion that career changes affecting 3-14\% of the labour force would be needed (McKinsey 2017). It has also examined the percentage of industrial jobs by country that could be automated and showed that $26 \%$ for Japan and $5 \%$ for Kenya are the two extreme ratios. Further optimistic studies have also been released, one of which is the analysis of the World Economic Forum (WEF 2016), based on corporate surveys and covering 1.86 billion sample of employees in 15 countries. It was found that 2 million new and 7-10 million terminated jobs are to be expected in those countries. The analysis of Tuomisto (2016), based on secondary data analysis and a global approach, came to the conclusion that a significant part of jobs would be transformed, and to ensure the best possible technological adaptation and least social shock, more colourful and democratic organisations should evolve. Berger (2016) also studied the possible changes in Western Europe, using labour market modelling and assuming that Industry 4.0 solutions would have a proliferation rate of $50 \%$ by 2035 . The analysis concluded that the number of industrial employees would first increase, then decrease. On the whole, there will be 1.4 million new jobs in Europe. But other jobs would also be affected, so 10 million new jobs would emerge, $70 \%$ of these are among service companies.

The literature of the past years indicated very different rates and structures for the direct and indirect employment effects of Industry 4.0 (Mckinsey 2017; Acemoglu - Restrepo 2019). This phenomenon does not refer to the changes over time concerning a specific country only, but also to the diversity of expectations by region. Projection is made more difficult by the fact that the long-term trends of employment are highly similar in various regions, depending on their economic development levels. The share of industry and construction fluctuates slightly, the share of agriculture diminishes, and the weight of services increases (Piketty 2014). Table 1

Table 1. Number of employed persons and ratio of industrial/construction employees in Hungary (1998, 2008 and 2018)

\begin{tabular}{|l|c|c|c|}
\hline & Employed persons, total (thousands) & $\begin{array}{c}\text { Employed persons in industry and } \\
\text { construction (thousands) }\end{array}$ & Ratio \\
\hline 1998 & 3695.6 & 1267.3 & 34.3 \\
\hline 2008 & 3848.3 & 1231.9 & 32 \\
\hline 2018 & 4469.5 & 1445.9 & 32.3 \\
\hline
\end{tabular}

Source: authors, based on KSH (2018). 
reflects similar developments: in Hungary, the ratio of industrial and construction employees decreased between 1998 and 2008, and slightly increased between 2008 and 2018 (KSH 2018).

The picture is further differentiated by the fact that one of the key goals of public social policy, and labour market policy within it, is to prevent long-term unemployment on account of its significant potential negative social and economic effects for a given society (Frey 2007; Öry 2005). Obviously, this statement could be criticised from many perspectives, but the effect of the - alleged or actual - problem is demonstrated by the fact that, whereas the EU currently contributes around 19\% of global GDP, its share in global social transfers is around 35\% (ILO 2014). Considering the changes in public social protection expenditures compared to GDP in the countries globally, it can be seen that they rose from 5.8 to $8.6 \%$ between 1990 and 2010, whereas in Western Europe the corresponding figures were 20.9 and 26.7\% (ILO 2014).

Under the combined effects of a social policy driven by similar intentions, a public work programme complementing it and the increasingly perceptible labour shortage, the employment rate of the 20-64 year-old with maximum eight-year primary education has been increasing in Hungary, according to the data of the Hungarian Central Statistical Office, from $36.1 \%$ in 2010 to $53.9 \%$ in 2017 .

One must not disregard the effect of the digital revolution on organisational structures. Notably, in April 2008, Vermont was the first state in the US where a new enterprise form, the low-profit limited liability corporation, L3C, was licensed. L3C functions as a for-profit company, generating a minimum amount of profit but geared primarily towards producing a significant social benefit of some kind (Pink 2010).

\section{CHARACTERISTICS OF THE HUNGARIAN LABOUR MARKET}

Data of from the EU's Survey of Income and Living Conditions (EU-SILC) for Hungary (with the reference year of 2018) served as a basis for our microsimulation modelling. It contains information on the employment status and income by detailed income categories on 25,000 individuals. The EU-SILC is based on the idea of a common framework consisting of common procedures, concepts, classifications and target variables. However, the dataset is only partly representative by sector, region and educational attainment; therefore, we also used the official Eurostat data (Labour Force Statistics) for analysing the recent characteristics of the Hungarian labour market and for making international comparison.

As Fig. 1 shows, the Hungarian employment structure is much more product than service oriented than the EU average. In Hungary, one out of five employees work in industry, while in the EU this is almost 5\% points less. Employment in the service sectors (professional, scientific activities, education, heath, etc.) is significantly lower in Hungary. These structural differences can signal that the Hungarian labour market might face extraordinary challenges to be able to meet the requirements of Industry 4.0 (e.g., new type of skills, new forms of work, etc.) for the years to come.

As shown in Table 2, employment structure and employment rates vary significantly by educational attainment between the EU and Hungary. In Hungary, only a fourth of employees have tertiary education while it is more than one third in the EU. On the other hand, the ratio of people with less than secondary education (ISCED levels 0-2) is much lower in Hungary than it is in the $\mathrm{EU}$ on average. This could indicate a favourable position in combating the 


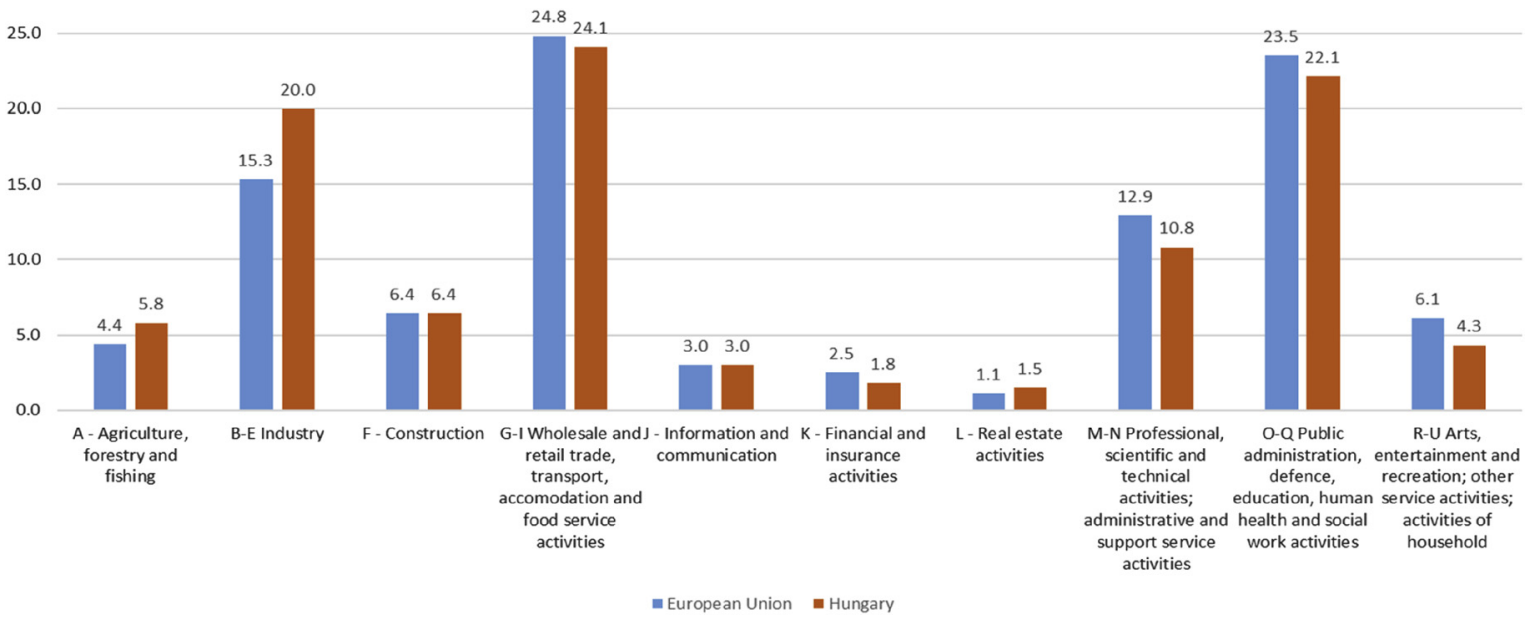

Figure 1. Employment (15-64 years of age) by sector, in Hungary and the EU, 2017 (as percentage of total)

Source: authors, based on Eurostat Labour Force Statistics 
Table 2. Employment and employment rate by the highest educational attainment (from 15 to 64 years), 2017

\begin{tabular}{|l|c|c|c|c|}
\hline \multirow{2}{*}{ Highest educational attainment } & \multicolumn{2}{|c|}{ Employment } & \multicolumn{2}{c|}{ Employment rate } \\
\cline { 2 - 5 } & EU & Hungary & EU & Hungary \\
\hline $\begin{array}{l}\text { Less than primary, or primary and lower } \\
\text { secondary education (levels 0-2) }\end{array}$ & 17.7 & 11.9 & 45.5 & 38.5 \\
\hline $\begin{array}{l}\text { Upper secondary, post-secondary, or non-tertiary } \\
\text { education (levels 3-4) }\end{array}$ & 48.0 & 62.3 & 70.9 & 73.1 \\
\hline Tertiary education (levels 5-8) & 34.3 & 25.8 & 84.0 & 84.3 \\
\hline Total & 100.0 & 100.0 & 67.6 & 68.2 \\
\hline
\end{tabular}

Source: authors, based on Eurostat Labour Force Statistics.

consequences of the expected sharp decrease in demand for low-skilled workforce. Analysing the employment rate figures shows that the best channel to increase the employment rate would be to increase the ratio of employees with tertiary education. The employment rate in this category is around $84 \%$ in the EU and Hungary, and the demand is expected to increase further for the next decades.

\section{MICROSIMULATION MODELLING: METHODOLOGY, ASSUMPTIONS AND PROJECTION OF SPILLOVER EFFECTS}

\subsection{Methodology}

The economic consequences of changing populations are frequently analysed. Our analysis uses the EU-SILC micro-datasets as a starting point, which are available to researchers carrying out statistical analyses for scientific purposes. These micro-data refer both to individuals and households. For the analysis, we used the individual level EU-SILC Hungary 2018 dataset, where individual data were anonymized in such a way that the statistical units could not be identified. Our microsimulation dataset consists of all current household members aged 16 years and over, of the EU-SILC 2018 database. The EU-SILC data collection refers to private households living in the territory of Hungary. The personal level variables are regrouped into five domains: demographic data, education, health, labour and income.

The following steps were followed during the modelling process.

1. Aging of the dataset (based on the assumed macroeconomic demographic projections). In scenario 1, the EUROPOP baseline was applied, while in scenarios 2 and 3, the demographic projection of HCSO Demographic Research Institute (HCSO DRI) was used. All the original personal weights (personal cross sectional weights from the personal register file) were modified to meet the requirement regarding the size and the structure of the Hungarian population in 2030). 
2. Uprating the microsimulation dataset taking into account the projected macroeconomic development by 2030. In terms of uprating employment, the expected employment growth was disaggregated by industry, and workers in dependent employment were divided into 18 categories. Specific uprating factors were applied to account for employment growth by industry from 2018 to 2030, based on the assumptions in the different scenarios. In scenarios 1 and 2, the CEDEFOP employment projection by industry was applied to the individuals working in a specific industry, while in scenario 3, a smaller employment growth and different structure was projected as a consequence of the assumed skill mismatch. To uprate the wage rates, the standard assumption is that everyone's income from a given source changes by the same rate over the relevant period. This would clearly be unrealistic and would understate distributional changes. In this paper, expected earnings growth was disaggregated by industry, so workers in dependent employment were also divided also into 18 categories. Specific uprating factors were applied to account for earnings growth of employees by industry from 2018 to 2030, based on the assumptions in the different scenarios of the assumed labour-market conditions.

3. Calculating gross and net income for each individual. We adjusted the value of the gross earnings variable for each individual based on the assumed changes in sectoral employment and wage developments. We calculated net income for each individual in the dataset assuming no changes in the personal income tax system (rates, tax credits, etc.) for the forecasted period.

4. Aggregating the results by income categories (deciles), by the highest educational attainment, by region, calculating inequality measures based on the output micro-dataset.

This widely used "top-down" microsimulation methodology facilitates the analysis of the distributional impacts of "nowcasted" or projected macroeconomic development.

\subsection{Assumptions for demographic trends in Hungary}

The last Hungarian medium-term employment projection was made around ten years ago. The 2014-20 employment strategy of the government included no projections (NGM 2014). HCSO's Demographic Research Institute (HCSO DRI), on the other hand, draws up projections on a regular basis (Földházi 2014). According to the latest data, by 2030, Hungary will have a population of 9,047,175, corresponding to a 9.2\% decrease relative to 2017 (Földházi 2015). According to the Eurostat projection, for the same period, the population of Hungary will change only slightly (Eurostat 2019). A difference of almost half a million people can be seen between these two population projections, which mainly stems from the different assumptions for migration inflows to Hungary.

Assumptions based on these sources for the applied scenarios are presented in Table 3.

In the first scenario in Table 3, we applied the official "Europop 2015" baseline projections for Hungary. Based on this, the population of Hungary was projected to decrease at a much lower rate (only a $2.6 \%$ decrease was projected compared to the population in 2018), which would mean that at about 9.6 million people living in Hungary in 2030. Change in employment is expected to be driven by the service sectors and the most popular occupations will be "office associate professionals" and "researchers \& engineers". They also argue that the majority of total job openings in 2030 will be for higher-level qualifications. Regarding the CEEFOP labour force estimations, a stagnation $(0.1 \%$ decrease) was projected. In terms of employment, even a very 
Table 3. Economic activity of the Hungarian population, 2018-2030, in percentage change

\begin{tabular}{|l|c|c|c|c|}
\hline & $\begin{array}{c}2018 \text { (thousand } \\
\text { persons) }\end{array}$ & $\begin{array}{c}\text { 2030 Scenario 1: } \\
\text { CEDEFOP projection }\end{array}$ & $\begin{array}{c}\text { 2030 Scenario 2: } \\
\text { HCSO DRI population } \\
\text { + no skill mismatch }\end{array}$ & $\begin{array}{c}\text { 2030 Scenario 3: } \\
\text { HCSO DRI population } \\
\text { + severe skill } \\
\text { mismatch }\end{array}$ \\
\hline Employed & $4,469.5$ & $5.3 \%$ & $-2.3 \%$ & $-11.6 \%$ \\
\hline Total population & $9,778.4$ & $0.1 \%$ & $-5.7 \%$ & $-5.7 \%$ \\
\hline
\end{tabular}

Source: authors, based on data from HCSO DRI and CEDEFOP (Europop 2015 baseline).

small increase $(0.4 \%)$ was projected, mainly due to the increase in the employment rate for persons aged more than 50 years.

In the second and third scenarios, we applied the HCSO DRI baseline population projection, which was based on the cohort-component method, which calculates the population size by age and sex for every successive year. In this projection (in the baseline scenario), the total fertility rate was expected to be 1.6, while life expectancy at birth was assumed to be 75.6 years for males and 82.4 years for females (Földházi 2015) by 2030. The net migration inflow was predicted negative, but only as low as 5,960 persons. Based on these assumptions, a sharp population loss was projected by 2030 (9.05 million people, a 6\% decrease from 2018 to 2030). Regarding the age structure, the share of the young and middle-age cohorts was projected to shrink, while the number and share of older people (above 65 years) was expected to reach 2.1 million. In other words, both the old age dependency ratio (the ratio between the number of persons above 65 and the number of working-age persons between 15 and 64 years) and the aging index (the ratio between the number of persons above 65 and the number of persons aged less than 15 years) was projected to deteriorate quite sharply.

We then applied different scenarios to determine the expected size and structure of Hungarian employment. We have reweighted the dataset based on our assumptions, assigning bigger weights to persons (records) whose job belonged to sectors with higher projected dynamics, and smaller weights to those who work in a sector expected to shrink significantly. Then, we assumed the expected real wage changes by sector, by 2030. Finally, the expected incomes were calculated at first on the micro-level, then aggregate results were calculated by decile, educational attainment and regions. As a last step, we analysed the changes in inequalities and the possible social consequences.

\subsection{Assumptions for the wage and employment dynamics by sector}

The underlying assumptions regarding the real wage forecasts were as follows: we assumed that sectors characterized by higher gross value added ratio (ICT services, manufacturing, etc.) would realize a relatively higher real wage increase due to the growing labour shortage with regard to the sectors where highly-skilled workforce is needed. On the other hand, wages in the government led sectors are expected to increase at a much lower rate. On the whole, we assumed a $1.5-2 \%$ annual real wage increase favouring the highly skilled flexible workforce at a significantly higher rate. Regarding our employment forecasts, we used the two scenarios of the HCSO DRI and CEDEFOP discussed in the previous section. The labour market consequences of these different assumptions can be seen in Table 4 . 
Table 4. Future employment and real wage growth in Hungary by sector between 2018 and 2030 (\%)

\begin{tabular}{|c|c|c|c|c|c|c|}
\hline & $\begin{array}{c}\text { Scenario } \\
\text { 1: } \\
\text { CEDEFOP }\end{array}$ & $\begin{array}{c}\text { Scenario 2: } \\
\text { HCSO DRI + } \\
\text { no skill } \\
\text { mismatch }\end{array}$ & $\begin{array}{l}\text { Scenario 3: } \\
\text { HCSO DRI } \\
\text { severe skill } \\
\text { mismatch }\end{array}$ & $\begin{array}{l}\text { Scenario } \\
\text { 1: } \\
\text { CEDEFOP }\end{array}$ & $\begin{array}{c}\text { Scenario 2: } \\
\text { HCSO DRI + } \\
\text { no skill } \\
\text { mismatch }\end{array}$ & $\begin{array}{l}\text { Scenario 3: } \\
\text { HCSO DRI } \\
\text { severe skill } \\
\text { mismatch }\end{array}$ \\
\hline & \multicolumn{3}{|c|}{ Employment } & \multicolumn{3}{|c|}{ Real wage growth } \\
\hline $\begin{array}{l}\text { A - Agriculture, } \\
\text { forestry and } \\
\text { fishing }\end{array}$ & -45.3 & -33.0 & -20.0 & 81.7 & 74.3 & 46.4 \\
\hline $\begin{array}{l}\text { B - Mining and } \\
\text { quarrying }\end{array}$ & -8.6 & -19.0 & -25.0 & 60.0 & 54.6 & 34.1 \\
\hline C - Manufacturing & 0.9 & -3.0 & -12.0 & 122.0 & 111.0 & 112.6 \\
\hline $\begin{array}{l}\text { D - Electricity, gas, } \\
\text { steam and air } \\
\text { conditioning } \\
\text { supply }\end{array}$ & 10.4 & 25.0 & -12.0 & 60.0 & 54.6 & 55.4 \\
\hline $\begin{array}{l}\text { E - Water supply; } \\
\text { sewerage, waste } \\
\text { management } \\
\text { and remediation } \\
\text { activities }\end{array}$ & -17.9 & 5.0 & -11.6 & 75.5 & 68.7 & 69.7 \\
\hline F - Construction & 2.9 & -22.0 & -15.0 & 91.0 & 82.8 & 64.6 \\
\hline $\begin{array}{l}\text { G - Wholesale and } \\
\text { retail trade; } \\
\text { repair of motor } \\
\text { vehicles and } \\
\text { motorcycles }\end{array}$ & 7.6 & -22.0 & -9.0 & 29.0 & 26.4 & 16.5 \\
\hline $\begin{array}{l}\text { H - Transportation } \\
\text { and storage }\end{array}$ & -8.5 & -2.0 & -11.6 & 44.5 & 40.5 & 41.1 \\
\hline $\begin{array}{r}\text { I- Accommodation } \\
\text { and food service }\end{array}$ & -27.4 & -13.0 & -5.0 & 44.5 & 40.5 & 25.3 \\
\hline $\begin{array}{l}\text { J - Information and } \\
\text { communication }\end{array}$ & 0.5 & 25.0 & -11.6 & 153.0 & 139.2 & 200.0 \\
\hline $\begin{array}{l}\mathrm{K} \text { - Financial and } \\
\text { insurance } \\
\text { activities }\end{array}$ & 37.2 & 23.0 & -10.0 & 29.0 & 26.4 & 26.8 \\
\hline $\begin{array}{l}\text { L - Real estate } \\
\text { activities }\end{array}$ & 46.5 & -7.0 & -11.6 & 29.0 & 26.4 & 16.5 \\
\hline
\end{tabular}

(continued) 
Table 4. Continued

\begin{tabular}{|c|c|c|c|c|c|c|}
\hline & $\begin{array}{c}\text { Scenario } \\
\text { 1: } \\
\text { CEDEFOP }\end{array}$ & $\begin{array}{c}\text { Scenario 2: } \\
\text { HCSO DRI } \\
\text { no skill } \\
\text { mismatch }\end{array}$ & $\begin{array}{c}\text { Scenario 3: } \\
\text { HCS0 DRI } \\
\text { severe skill } \\
\text { mismatch }\end{array}$ & $\begin{array}{c}\text { Scenario } \\
\text { 1: } \\
\text { CEDEFOP }\end{array}$ & $\begin{array}{c}\text { Scenario 2: } \\
\text { HCSO DRI } \\
\text { no skill } \\
\text { mismatch }\end{array}$ & $\begin{array}{c}\text { Scenario 3: } \\
\text { HCSO DRI } \\
\text { severe skill } \\
\text { mismatch }\end{array}$ \\
\cline { 2 - 7 } & \multicolumn{3}{|c|}{ Employment } & \multicolumn{3}{|c|}{ Real wage growth } \\
\hline $\begin{array}{c}\text { M - Professional, } \\
\text { scientific and } \\
\text { technical } \\
\text { activities }\end{array}$ & 46.5 & 20.0 & -11.4 & 44.5 & 40.5 & 200.0 \\
\hline $\begin{array}{c}\text { N - Administrative } \\
\text { and support } \\
\text { service activities }\end{array}$ & 5.2 & -9.0 & -11.6 & 29.0 & 26.4 & 16.5 \\
\hline $\begin{array}{c}\text { 0 - Public } \\
\text { administration } \\
\text { and defence; } \\
\text { compulsory } \\
\text { social security }\end{array}$ & -3.7 & -25.0 & -18.0 & 13.5 & 12.3 & 7.7 \\
\hline P - Education & 15.5 & -1.0 & -8.0 & 13.5 & 12.3 & 12.5 \\
\hline $\begin{array}{c}\text { Q - Human health } \\
\text { and social work } \\
\text { activities }\end{array}$ & 33.7 & 50.0 & -4.0 & 29.0 & 26.4 & 26.8 \\
\hline $\begin{array}{c}\text { R - Arts, } \\
\text { entertainment } \\
\text { and recreation }\end{array}$ & 11.0 & 0.0 & -8.0 & 13.5 & 12.3 & 9.6 \\
\hline
\end{tabular}

Source: authors, based on HCSO DRI and CEDEFOP.

\subsection{Projections and main findings}

Figure 2 shows the results of our impact assessment for the income distributions by decile in 2018 (base) and for 2030. It can be seen that all the three scenarios show a significant increase in inequality compared to the state of 2018. Scenarios 1 and 2 (CEDEFOP projection and HCSO DRI projection with no skill mismatch) show a similar evolution of inequalities, but the third scenario shows a significantly different picture: only situation of the richest two deciles improves significantly, while the relative income position of all other deciles deteriorates. While the income share of the poorest $20 \%$ was $6.4 \%$ in 2018 , it is projected to decrease to $5 \%$ for 2030 in scenario 3. This scenario indicates that the skill mismatch can be the real problem in 2030, since the higher labour shortage may result in larger wage differentiation and this will lead to higher income polarisation irrespective of the extent of immigration.

Table 5 shows no or just small changes in the distribution of employed people by the highest educational attainment. The distribution of different educational attainment levels was calculated by reweighting based on the assumed employment trends. No major structural change in 


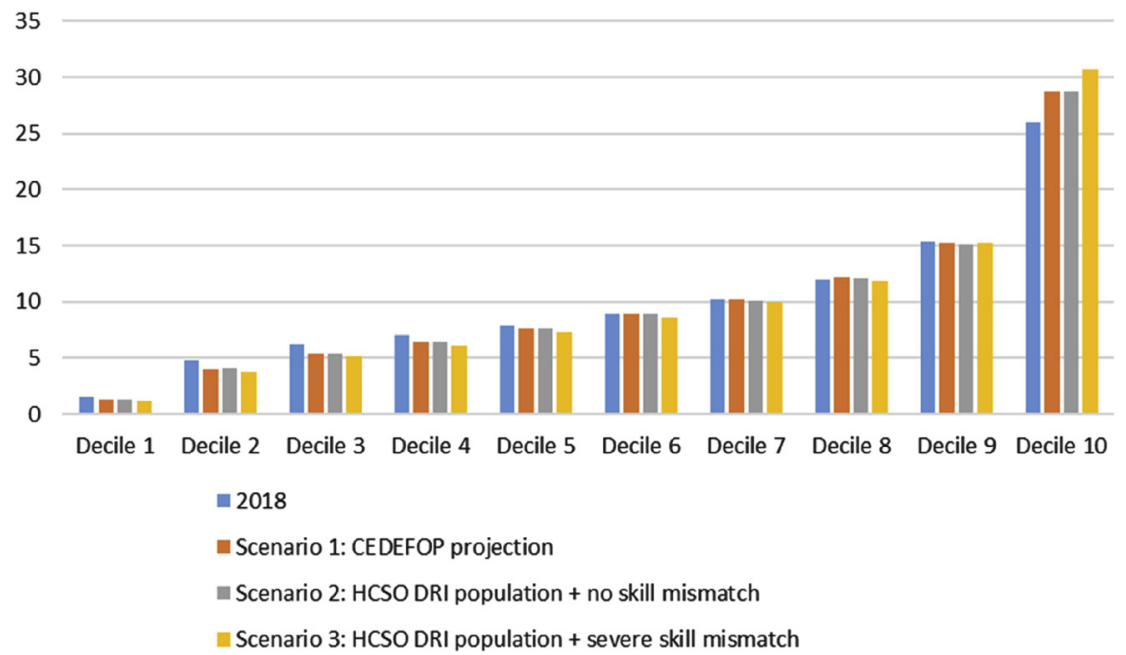

Figure 2. Income distribution of the employed by decile, 2018 and 2030 (Employee cash or near cash income, in percentage of total income)

Source of data: authors, based on data from EU-SILC Hungary

the educational distribution was taken into account. It does not mean that structural changes would not be necessary in the Hungarian educational system corresponding to the needs of the Hungarian labour market; it just shows that the expected changes in labour demand do not generate the necessary changes automatically. The demand for high-skilled workforce will definitely increase in the majority of sectors, therefore, active economic policy tools would be needed to generate the labour supply with necessary skills and educational attainment. A

Table 5. Distribution of employed people by the highest educational attainment, 2018 and 2030 (in percentage of total employed)

\begin{tabular}{|l|c|c|c|}
\hline & \multicolumn{3}{|c|}{ Highest education attainment } \\
\cline { 2 - 4 } & Primary education & Secondary education & Tertiary education \\
\hline 2018 & 13.3 & 62.3 & 24.5 \\
\hline Scenario 1: CEDEFOP projection (2030) & 12.5 & 61.4 & 26.1 \\
\hline $\begin{array}{c}\text { Scenario 2: HCSO DRI population + no } \\
\text { skill mismatch (2030) }\end{array}$ & 12.2 & 62.0 & 25.7 \\
\hline $\begin{array}{c}\text { Scenario 3: HCSO DRI population }+ \\
\text { severe skill mismatch (2030) }\end{array}$ & 13.0 & 62.4 & 24.6 \\
\hline
\end{tabular}

Source of data: authors, based on data from EU-SILC Hungary. 
positive outcome can emerge if higher demand towards high-skilled workers, associated with higher income, decreases the emigration of high-skilled employees.

In 2018, average employee cash or near cash income was $15 \%$ higher in Central Hungary than the Hungarian average. Figure 3 also shows that some moderate territorial restructuring is projected by each scenario. The positive wage advantage is expected to increase in Central Hungary only in the third scenario, while positions of Central and Western Transdanubia are projected to improve in all the three scenarios. Unfortunately, the most disadvantaged regions (Northern Hungary, Northern and Southern Great Plain) are not expected to catch up just because the sectoral labour demand changes.

In Table 6, we summarize the spill-over effects of the simulated labour market changes on income and income inequality changes. The median income is projected to grow significantly in each scenario, but the increase is a bit more dynamic in the first scenario (EUROPOP projection with no skill mismatch), where a more advanced adjustment of labour supply to the new requirements was assumed as a result of implementing a more developed lifelong learning system and some other active labour market policy tools. It can also be seen that income inequalities are

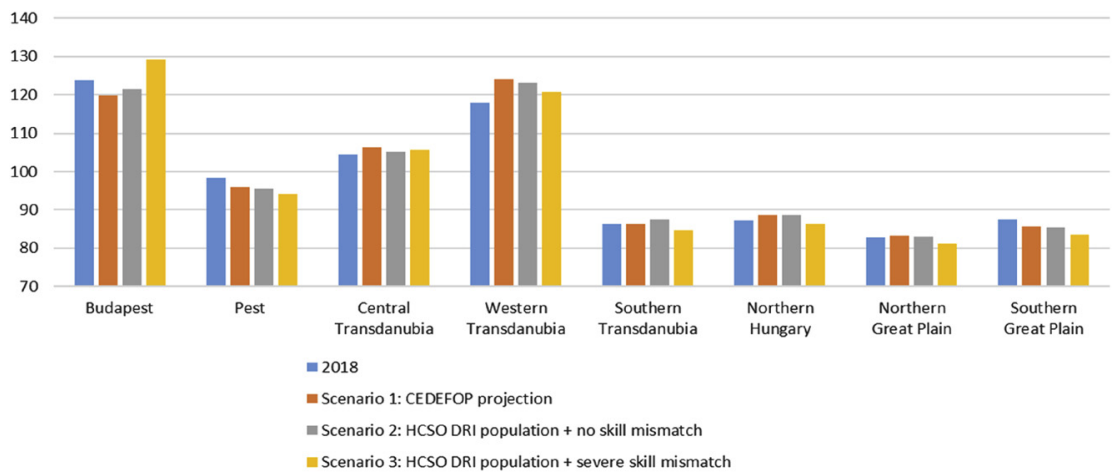

Figure 3. Employee cash or near cash income (gross) by region, 2018 and 2030 (national average $=100$ )

Table 6. Evolution of different measures of inequality in Hungary, 2018-2030

\begin{tabular}{|c|c|c|c|c|}
\hline & \multirow{2}{*}{$\begin{array}{c}S 80 / S 20 \\
6.5\end{array}$} & \multirow{2}{*}{$\begin{array}{c}\text { Gini } \\
0.333\end{array}$} & \multirow{2}{*}{$\begin{array}{l}\text { Median income } \\
2,094,103\end{array}$} \\
\hline Base & 2018 & & & \\
\hline Scenario 1: CEDEFOP projection & 2030 & 8.2 & 0.371 & $3,280,829$ \\
\hline $\begin{array}{l}\text { Scenario 2: HCSO DRI population + no skill } \\
\text { mismatch }\end{array}$ & 2030 & 8.1 & 0.368 & $3,217,528$ \\
\hline $\begin{array}{l}\text { Scenario 3: HCSO DRI population + severe } \\
\text { skill mismatch }\end{array}$ & 2030 & 9.2 & 0.393 & $3,102,879$ \\
\hline
\end{tabular}

Source of data: authors, based on data from EU-SILC Hungary. 
expected to increase in each scenario irrespectively of the different assumptions about the future demographic trends, and about the different equilibrium/non-equilibrium situations on the labour market. However, the most significant changes were calculated in scenario 3, where we projected a significant labour shortage of high-skilled workers and a larger wage differentiation due this tendency. In this scenario, the income quantile share ratio would increase by almost $50 \%$, and the Gini coefficient would come close to 0.4 . To avoid this unfavourable and unsustainable prospect for the future, smart, intense and effective economic policy steps should be taken to help preparing the labour force for the challenges in the future labour market.

\section{CONCLUSION}

This paper focused on quantifying the indirect spill-over effects of the expected sectoral changes in labour demand in Hungary up to 2030. We elaborated three scenarios: two were based on the official demographic projections of HCSO DRI, while the remaining one used the latest CEDEFOP employment forecasts. In scenario 2, we assumed that the labour supply by sector, occupation and the highest educational attainment would change significantly by 2030 (by implementing new incentives and initiatives by the government) and in this way, severe skill mismatches could be avoided in the future labour market. In scenario 3, we assumed no significant changes in the Hungarian education system and in labour market policy. Wage forecasts by sector, based on the specific demand-supply estimations, were determined in each scenario. Then the spill-over effects of the expected labour demand changes on the average wage levels and inequalities by sector, region and the highest educational attainment were calculated.

The results indicate that structural labour demand changes could cause a moderate income polarisation in scenarios 1 and 2 . In these cases, the regional inequalities are expected to remain more or less stable but significant. It is quite an interesting and a bit unexpected result that the increase in inequalities is quite similar and limited in these scenarios, i.e. irrespective of the assumptions concerning the size of the net migration. In scenario 3, we assumed that the preparation for the "future of work" will not be perfectly smooth in Hungary. Restructuring of the Hungarian labour market is on the horizon, but the speed of structural changes in skills, occupations and increase in the ratio of people with tertiary education is not sufficient yet. Based on our calculations in scenario 3, we argue that the most important challenge for Hungary is not only to cope with the consequences of the new labour demand by sector, but also to establish a new labour market equilibrium in terms of sectors and skill level, giving the opportunities for people to get the new skills and necessary knowledge. Otherwise, the significant skill mismatches could cause severe problems in the labour market, decreasing long-term economic growth prospects and inducing significant income polarisation due to the larger wage gaps and higher unemployment rates. Based on our microsimulation results, it can be concluded that the most important challenges for employees, employers and especially for the government are mainly connected to the country's performance regarding preparation for the future of work. Surprisingly to the demographic challenges regarding aging and migration for Hungarian economy by 2030 matter much less. As a consequence, it can be argued that new initiatives regarding life-long learning, programs supporting more flexible workplaces, government measures supporting digitalization and further development of the Hungarian tertiary education system could be of vital importance 
regarding longer term economic growth, and also it could help to avoid unsustainable income inequality trends in Hungary.

\section{ACKNOWLEDGEMENT}

This paper has been supported by the European Union and Hungary and co-financed by the European Social Fund through the project EFOP-3.6.2-16-2017-00017 entitled "Sustainable, intelligent and inclusive regional and city models".

\section{REFERENCES}

Acemoglu, D. - Restrepo, P. (2019): Automation and New Tasks: How Technology Displaces and Reinstates Labor. Journal of Economic Perspectives 33(2): 3-30.

Arntz, M. - Gregory, T. - Zierahn, U. (2016): The Risk of Automation for Jobs in OECD Countries: A Comparative Analysis. OECD Social, Employment and Migration Working Papers 189.

Atkinson, A. B. (2009): An Enlarged Role for Tax-Benefit Models. In: Lelkes, O. - Sutherland, H. (eds): Tax and Benefit Policies in the Enlarged Europe: Assessing the Impact with Microsimulation Models. Public Policy and Social Welfare. Farnham: Ashgate Publishing, pp. 33-46.

Bargain, O. - Callan, T. (2010): Analysing the Effects of Tax-Benefit Reforms on Income Distribution: A Decomposition Approach. Journal of Economic Inequality 8(1): 1-21.

Benedek, D. - Kiss, Á. (2011): Mikroszimulációs elemzés a személyi jövedelemadó módosításainak hatásvizsgálatában [Impact Assessment Analysis for Changes of Personal Income Taxation by Microsimulation]. Közgazdasági Szemle 58(2): 97-110.

Benedek, D. - Lelkes, O. (2006): A magyarországi jövedelem-újraelosztás és egy egykulcsos adóreform vizsgálata mikroszimulációs modellel [Analysis of Income Redistribution and the Flat Tax Rate in Hungary]. Közgazdasági Szemle 53(7-8): 604-623.

Berger, R. (2016). The Industry 4.0 Transition Quantified. How the Fourth Industrial Revolution is Reshuffling the Economic, Social and Industrial Model. Boston: Roland Berger Llc.

Bitler, M. P. - Gelbach, J. B - Hoynes, H. W (2006): What Mean Impacts Miss: Distributional Effects of Welfare Reform Experiments. American Economic Review 96(4): 988-1012.

Bourguignon, F. - Bussolo, M. - Pereira Da Silva, L. A. (eds) (2008): Impacts of Macroeconomic Policies on Poverty and Income Distribution: Macro-micro Evaluation Techniques and Tools. Basingstoke and Washington DC: Palgrave and the World Bank.

Bourguignon, F. - Spadaro, A. (2006): Microsimulation as a Tool for Evaluating Redistribution Policies. Journal of Economic Inequality 4(1): 77-106.

CEDEFOP (2018): Skills Forecast for Hungary. https://www.cedefop.europa.eu/files/cedefop_skills_ forecast_2018_-_hungary.pdf, accessed 19/04/2020.

Cette, G. - Lopez, J. - Mairesse, J. (2016). Labour Market Regulations and Capital Intensity. NBER Working Papers 22603.

Colombo, G. (2010): Linking CGE and Microsimulation Models: A Comparison of Different Approaches. International Journal of Microsimulation 3(1): 72-91. 
Cserháti, I. - Dobszayné Hennel, J. - Havasi, É. - Keresztély, T. - Kővári, Z. - Szép, K. - Takács, T. - Tallér, A. - Tamási, B. - Varga, Z. (2007): A háztartások jövedelemalakulásának elemzése mikroszimulációs modellel [Analysis of Households' Income Distribution by Microsimulation]. Budapest: ECOSTAT KSH.

Cserháti, I - Keresztély, T. (2012): A megfigyelési egységektől a makrogazdasági aggregátumokig - a mikroszimulációs modellezés néhány módszertani kérdése [From the Observation Units to the Macroeconomic Aggregates - Some Methodological Issues of Microsimulation Modelling]. Statisztikai Szemle 88(7-8): 789-802.

Cserháti, I - Keresztély, T. - Takács, T. (2012) Examination of Income Inequalities of Hungarian Households in 2012 using a Microsimulation Model. Hungarian Statistical Review 2012(Special Number 16): 3-17.

Cserháti, I. - Takács, T (2010): Analysis of Income Inequalities by Microsimulation. Hungarian Statistical Review 2010(Special Number 14): 110-124.

Cserháti, I. - Takács, T (2018): Potential Job Losses due to Automation and its Impact on Poverty Gap in Hungary. WSEAS Transactions on Business and Economics 2019(6): 47-53.

Deloitte (2019): The Deloitte Global Millennial Survey. https://www2.deloitte.com/content/dam/Deloitte/ global/Documents/About- Deloitte/deloitte-2019-millennial-survey.pdf, accessed 19/04/2020.

Eurostat (2019): Population, Demography and Migration Projections. https:/ec.europa.eu/eurostat/web/ population-demography-migration-projections/data/database, accessed 19/04/2020.

Fine, D. - Havas, A. - Hieronimus, S. - Jánoskuti, L. - Kadocsa, A. - Puskás, P. (2018): Transforming our Jobs: Automation in Hungary. McKinsey\&Company.

Földházi, E. (2015): A népesség szerkezete és jövője [Structure and Future of the Population]. In: Monostori, J. - Öri, P. - Spéder, Z. (eds): Demográfiai portré 2015 [Demographic Portrait, 2015]. Budapest: KSH NKI.

Földházi, E. (2014): Magyarország népességének várható alakulása 2060-ig - különös tekintettel a nemzetközi vándorlásra. [Expected Demographic Trends on Hungary with Special Regard to the International Migration]. Demográfia 2014(4): 241-269.

Frey, C. B. - Osborn, A. M. (2013): The Future of Employment: How Susceptible are Jobs to Computerisation? Oxford: Oxford Martin School.

Frey, M., ed. (2007): Szociális gazdaság kézikönyv [Handbook on Social Economy]. Budapest: Országos Foglalkoztatási Közalapítvány.

Fülöp, Z. (2018): Az Ipar 4.0 foglalkoztatásra gyakorolt hatása [Impacts of Industry 4.0 on Employment]. Munkaügyi Szemle 2018(6): 56-64.

Gupta, A - Kapur, V. eds. (2000): Microsimulation in Government Policy and Forecasting. Elsevier Science.

ILO (2014): World Social Protection Report 2014-15: Building Economic Recovery, Inclusive Development and Social Justice. Geneva: ILO.

Isson, J. P. - Harriott, J. S. (2016): People Analytics in the Era of Big Data: Changing the Way You Attract, Acquire, Develop, and Retain Talent. Hoboken, NJ: Wiley.

KSH (2018): A foglalkoztatottak száma nemzetgazdasági ágak, ágazatok szerint [Number of the employed by branches and sectors of the national economy]. https://www.ksh.hu/docs/hun/xstadat/xstadat_eves/ i_qlf005a.html, accessed 19/04/2020.

Landmann, J. - Heumann, S. (2016): Toward the Labor Market 4.0? Potential Impacts of Digitization on Labor and Employment in Germany until 2030. https://www.bertelsmann-stiftung.de/en/publications/ publication/did/toward-the-labor-market-40/, accessed 19/04/2020.

Mckinsey (2017): Jobs Lost, Jobs Gained: Workforce Transitions in a Time of Automation. McKinsey Global Institute Discussion Papers 2017(12). 
Morgan Stanley (2016): The Internet of Things and the New Industrial Revolution. Morgan Stanley Research Papers 2016(3).

Nábelek, F. - Sturcz, A. - Tóth, I. J. (2016): Az automatizáció munkaerő-piaci hatásai. járási munkaerőpiacok automatizációs kitettségének becslése. [Labour Market Effects of Automation - Estimating the Impacts on Micro-region Level]. Magyar Kereskedelmi és Iparkamara Gazdaság és Vállalkozáskutató Intézet Research Papers 2016(4).

NGM (2014): A 2014-2020 közötti idöszak foglalkoztatáspolitikai célú fejlesztéseinek megalapozása szakpolitikai stratégia [Foundation of the employment policy developments of the period of 2014-2020] https://ngmszakmaiteruletek.kormany.hu/download/a/4c/c0000/Fogl_Strat_14-20_elfogadott.pdf, accessed 19/04/2020.

Norton, A. (2017): Automation and Inequality: The Changing World of Work in the Global South. IIED Issue papers $2017(8)$.

Orcutt, G. H. (1960): Simulation of Economic Systems. The American Economic Review 50(12): 894-907.

Öry, M. (2005): Hátrányos helyzetü csoportok helyzete a munkaeröpiacon [Labour Market Situation of Disadvantaged Groups]. https://mek.oszk.hu/06400/06453/06453.pdf, accessed 19/04/2020.

Paulus, A. - Cok, M. - Figari, F. - Hegedüs, P. - Krump, N. - Lelkes, O. - H, Levy - Lietz, C. - Lipsik, S.Mantovani, D. - Morawski, L. - Sutherland, H. - Szivós, P. - Vörk, A. (2009): The Effects of Taxes and Benefits on Income Distribution in the Enlarged EU. EUROMOD Working Papers 8(9).

Peichl, A. (2009): The Benefits and Problems of Linking Micro and Macro Models - Evidence from a Flat Rate Analysis. Journal of Applied Economics 12(2): 301-329.

Piketty, T. (2014): Capital in the Twenty-first Century. Boston: The Belknap Press of Harvard University Press.

Pink, D. H. (2010): Motiváció 3.0 ösztönzés másképp. [Motivation 3.0; incentization in another way]. Budapest: HVG.

Pirisi, K. (2017): A közmunka szerepe a foglalkoztatáspolitikában, a szegénység és a hajléktalanság kezelésében [The Role of Public Works in Employment Policy and the Amelioration of Poverty and Homelessness]. PhD dissertation. Gödöllő: Szent Istvan Egyetem.

Rodrik, D. (2016). Premature Deindustrialization. Journal of Economic Growth. 21(1):1-33.

Sutherland, H. (1995): Static Microsimulation Models in Europe: A Survey. Cambridge Working Papers in Economics 9523.

Sutherland, H. - Figari, F. (2013): EUROMOD: The European Benefit-tax Model. International Journal of Microsimulation 6(1): 4-26.

Szívós, P. - Rudas, T. - Tóth, I. G. (1998): TÁRSZIM97 mikroszimulációs modell az adók és támogatások hatásvizsgálatára [Application of Microsimulation Model TARSZIM for Tax-benefit Analysis]. TÁRKI Társadalompolitikai Tanulmányok 10.

SZTAKI (2018): Az ipar 4.0 nemzeti technológiai platform - kérdöív projekt [Industry 4.0 National Technological Platform - Questionnaire Project]. https://www.i40platform.hu/sites/default/files/2018-04/ Flyer_v8.0_0.pdf, accessed 19/04/2020.

Tuomisto, V. (2016): The Resilient Workforce. The Economist Intelligence Unit Perspective Series 2016(8).

Verhofstadt, G. (2017): Why Europe should Lead the Way on AI and Robotics. https://www.weforum.org/ agenda/2017/12/why-europe-should-lead-the-way-on-ai-and-robotics?utm_

content $=$ buffer1c462\&utm_medium $=$ social\&utm_source $=$ twitter.com\&utm_campaign $=$ buffer, accessed 19/04/2020.

Wagenhals, G. (2004): Tax-Benefit Microsimulation Models for Germany: A Survey. Institut fuer Angewandte Wirtschaftsforschung Report 32. 
WEF (2016): The Future of Jobs, Employment, Skills and Workforce Strategy for the Fourth industrial revolution. Geneva: World Economic Forum.

Wike, R. - Stokes, B. (2018): In Advanced and Emerging Economies Alike, Worries about Job Automation. PEW Research Center.

Open Access. This is an open-access article distributed under the terms of the Creative Commons Attribution 4.0 International License (https://creativecommons.org/licenses/by/4.0), which permits unrestricted use, distribution, and reproduction in any medium, provided the original author and source are credited, a link to the CC License is provided, and changes - if any - are indicated. (SID_1). 